\title{
Transitiepsychiatrie: Bridging the Gap...
}

Citation for published version (APA):

Amelsvoort van, T. A. M. J. (2013). Transitiepsychiatrie: Bridging the Gap... Maastricht University. https://doi.org/10.26481/spe.20130118ta

Document status and date:

Published: 18/01/2013

DOI:

$10.26481 /$ spe.20130118ta

Document Version:

Publisher's PDF, also known as Version of record

\section{Please check the document version of this publication:}

- A submitted manuscript is the version of the article upon submission and before peer-review. There can be important differences between the submitted version and the official published version of record.

People interested in the research are advised to contact the author for the final version of the publication, or visit the DOI to the publisher's website.

- The final author version and the galley proof are versions of the publication after peer review.

- The final published version features the final layout of the paper including the volume, issue and page numbers.

Link to publication

\footnotetext{
General rights rights.

- You may freely distribute the URL identifying the publication in the public portal. please follow below link for the End User Agreement:

www.umlib.nl/taverne-license

Take down policy

If you believe that this document breaches copyright please contact us at:

repository@maastrichtuniversity.nl

providing details and we will investigate your claim.
}

Copyright and moral rights for the publications made accessible in the public portal are retained by the authors and/or other copyright owners and it is a condition of accessing publications that users recognise and abide by the legal requirements associated with these

- Users may download and print one copy of any publication from the public portal for the purpose of private study or research.

- You may not further distribute the material or use it for any profit-making activity or commercial gain

If the publication is distributed under the terms of Article $25 \mathrm{fa}$ of the Dutch Copyright Act, indicated by the "Taverne" license above, 
Prof. dr. Therese A.M.J . van Amelsvoort

FHML

Transitiepsychiatrie: Bridging the Gap 


\section{Transitiepsychiatrie: Bridging the Gap...}

Rede uitgesproken 18 januari 2013 door TAMJ van Amelsvoort

Bijzondere Leerstoel Transitiepsychiatrie

Faculteit Health, Medicine and Life Sciences 
Meneer de Rector Magnificus

Waarde collega's

Lieve vrienden en familie

Geweldig dat u allemaal gekomen bent!

\section{Inleiding}

Transitiepsychiatrie? "wat is dat?" , "Dat zegt me niets" , "nog nooit van gehoord". Deze vragen werden mij het afgelopen jaar herhaaldelijk gesteld wanneer ik vertelde wat mij begin dit jaar naar Maastricht gebracht had. Gelukkig heb ik vandaag de gelegenheid wat uitgebreider antwoord op deze vraag te geven. Transitiepsychiatrie: $U$ zult zich inderdaad vast afvragen of dit weer een nieuw mode woord is, net zoals woorden als transparantie, translationeel, transcultureel en andere trendy "trans" woorden die ons de afgelopen jaren om de oren zijn gevlogen. Het antwoord, mocht $u$ zo dadelijk in slaap vallen, is ia, transitie psychiatrie is een nieuw begrip binnen de psychiatrie, en ja het is "trendy", of ik probeer u er in ieder geval ervan overtuigen dat het "trendy" gaat worden. De komende 45 minuten ga ik $\mathrm{u}$ vertellen wat transitiepsychiatrie inhoudt, en hoe ik aan dit nieuwe vakgebied invulling zal gaan geven met betrekking tot de 3 domeinen die bij mijn leerstoel horen namelijk patientenzorg, onderwijs en wetenschappelijk onderzoek. Het woord transitie impliceert een overgang of een verandering van een conditie of situatie naar een andere en is dus een heel algemeen begrip. Het begrip transitie is in de somatische zorg niet nieuw. Goede zorgtransitie speelt een cruciale rol waar het patienten met complexe problematiek betreft bv ouderen of mensen met een lichamelijke en / of verstandelijke beperking. Hier is vaak behoefte aan langdurige, multidisciplinaire zorg welke zorgvuldige afstemming tussen hulpverleners vereist. Onze collega's van de somatische geneeskunde, die hierin vooruitlopen op psychiaters, gebruiken steeds vaker de term "transitional care" of "youth care". Hier wordt de overgang, transitie, van pediatrische naar volwassen zorg bedoeld bij jongeren met chronische gezondheidsproblemen zoals bv suikerziekte of reuma. In mijn vakgebied, de psychiatrie, wordt dus met transitional psychiatry, transitiepsychiatrie, het "grensgebied" of "overgangsgebied" tussen kinder en jeugd en volwassen psychiatrie bedoeld. En hoewel de term transitiepsychiatrie vrij nieuw is in Nederland, is transitiepsychiatrie in Engelstalige landen inmiddels een bekender begrip. De titel van mijn oratie suggereert dat er bij de transitie gaps, kloven, overbrugd moeten worden. Ik zal in deze oratie 3 gaps een voor een met $\mathrm{u}$ bespreken.

De bedoeling is dat de transitiepsychiatrie deze gaps gaat overbruggen.

\section{De grens van 18}

Voordat ik de 3 "gaps" met u zal bespreken wil ik het eerst over "de grens"' hebben. "Het grensgebied tussen kinder en jeugd en volwassen psychiatrie" Wat verstaan we daar precies onder? Formeel ligt deze grens bij 18 jaar. En formeel is de kinder- en jeugd psychiatrie het 
medisch specialisme dat zich bezig houdt met diagnostiek en behandeling van kinderen en jeugdigen met een psychische stoornis of vermoeden daarvan, in de leeftijd $0 \mathrm{t} / \mathrm{m} 17$ jaar, alsmede onderwijs, opleiding en wetenschappelijk onderzoek op dat gebied. Vanaf 18-jarige leeftijd heet dit medisch specialisme volwassen psychiatrie. De vraag is of deze scheiding bij 18 jaar in de psychiatrie terecht is? Ik denk van niet. Mede onder druk van overheid en zorgverzekeraars wordt deze grens bij 18 jaar in de praktijk echter vrij strict gehanteerd. Dit schot in de zorg op 18-jarige leeftijd is een rechtstreekse consequentie van het feit dat onze maatschappij wettelijk bepaald heeft dat men vanaf die leeftijd als volwassen, meerderjarig gezien wordt. Dit houdt ook in dat men geacht wordt handelingsbekwaam te zijn en dus voor al zijn of haar eigen rechtshandelingen zal moeten kunnen instaan. Als we terugblikken in de geschiedenis zien we dat deze grens niet altijd bij 18 jaar is getrokken. Rond de middeleeuwen lag de leeftijdsgrens voor meerderjarigheid op 25 jaar. Als men bedenkt dat de levensverwachting toen rond de 30-40 jaar was, was het leven toen grotendeels een kinderlijke aangelegenheid. Vanaf begin $19^{\mathrm{e}}$ eeuw is deze grens geleidelijk aan gezakt naar 18 jaar. Hoewel wettelijk gezien 18 jaar als grens voor meerderjarigheid geaccepteerd is rijst in toenemende mate de vraag of het terecht is dat we in de zorg vasthouden aan een definitie van volwassenheid alleen op basis van kalenderleeftijd. Meerderjarigheid is een juridisch begrip wat vooral vermogensrechtelijk van belang is.

Volwassenheid is echter een veel breder begrip dan meerderjarigheid en betekent zoveel als "geestelijk en lichamelijk volgroeid zijn en in staat zijn volledig onafhankelijk in de maatschappij te kunnen functioneren".

Op grond van deze definitie is er wat voor te zeggen om in de gezondheidszorg niet alleen de kalenderleeftijd te laten bepalen waneer iemand volwassen is, maar ook iemands stadium van ontwikkeling te laten mee wegen. In ons huidige zorgstelsel hanteren we nu dus eigenlijk meerderjarigheid en niet volwassenheid als maat voor de tweedeling kinder en jeugd en volwassen psychiatrie, en strict genomen zouden we eigenlijk van minderjarige en meerderjarige psychiatrie moeten. We weten inmiddels dat de biologische en sociaalemotionele ontwikkeling op18-jarige leeftijd vaak nog lang niet voltooid is. We weten ook dat juist rondom het 18e levensjaar veel psychiatrische stoornissen zich voor het eerst manifesteren. Vanuit dit perspectief bezien is het dus niet logisch, zelfs onwenselijk om precies dan een schot te plaatsen in ons psychiatrisch zorgstelsel. Misschien wordt het tijd voor een evaluatie. Ik ga u proberen te overtuigen dat het zowel vanuit wetenschappelijk als zorginhoudelijk oogpunt goed zou zijn om in de psychiatrie de scheiding die door de wettelijke kaders is aangebracht is bij 18 jaar los te laten. Overigens is het interessant te constateren dat een organisatie als de World Health Organization niet vasthoudt aan een grens bij 18 jaar als het gaat om het in kaart brengen van gezondheidszorgaspecten wereldwijd. Zij definiëren youth, of te wel jeugd, als de periode tussen 15 en 24 jaar, wat zo is afgesproken in 1985 in het kader van het internationale jaar van de jeugd. In deze oratie zal ik deze definitie van jeugd, dus periode van 15-24 jaar, ook hanteren. 


\section{De 1e gap}

Waarom zouden we ons nu specifiek richten op jeugdigen? Om daar een antwoord op te kunnen geven moeten we kijken naar resultaten van wetenschappelijk onderzoek. Van de ruim 7 miljard mensen op aarde zijn meer dan een kwart jongeren die tussen de 10 en 24 jaar oud zijn. Over de afgelopen 50 jaar heeft de gezondheid van deze groep minder vooruitgang geboekt dan die van kleine kinderen (Sawyer et al., 2012). Kenmerkend voor jeugdigen is dat ze steeds zelfstandiger beslissingen nemen onafhankelijk van volwassenen. Tegelijkertijd worden hun leeftijdsgenoten of peers steeds belangrijker voor ze en dus ook invloedrijker. Een ander kenmerk van deze leeftijdsfase is impulsief en soms roekeloos gedrag. Dit gedrag kan gevaarlijke consequenties hebben; Cijfers van de World Health Organization laten zien dat doodsoorzaak nummer 1 wereldwijd in deze leeftijdsgroep komt door ongelukken; doodsoorzaak nummer 2 door zelfverwonding of zelfbeschadiging.

Echter als je gaat kijken naar de ziektelast, wat een maat is voor de hoeveelheid "gezondheidsverlies", dan staan psychische stoornissen op de $\underline{\underline{1^{\mathrm{e}}} \text { plaats}}$, en deze is tijdens deze fase groter dan op elk ander moment gedurende het leven (WHO, 2009). In tegenstelling tot de meeste somatische ziektebeelden treffen deze psychische stoornissen met name jeugdigen. Tomas Insel, de directeur van het wereldberoemde Amerikaanse onderzoeksinstituut, National Institute of Mental Health zegt dan ook: "'mental disorders are the chronic disorders of the young" (Insel \& Fenton, 2005).

Het blijkt dat de drie kwart van de psychiatrische stoornissen zich voor het eerst manifesteren voor de leeftijd van 24 jaar, en de helft voor de leeftijd van 14 jaar (Kessler et al., 2005). Daarnaast, blijkt dat psychiatrische stoornissen bij jeugdigen vrijwel altijd gepaard gaat met andere problemen: in een recente Engelse studie, bleek dat $\underline{\mathbf{9 8 \%}}$ van jeugdige psychiatrische patienten, meer dan 1 probleem of hulpvraag had. Naast de psychiatrische stoornissen werden dakloosheid, werkloosheid, schoolproblemen, problemen in de thuissituatie, crimineel gedrag, middelenmisbruik en verstandelijk beperking vaak geobserveerd (Singh et al., 2010). Concluderend lijken jeugdigen extra kwetsbaar voor psychische problemen en dus reden genoeg om extra aandacht aan deze populatie te besteden. Bovendien, voorspellen psychische problemen op jonge leeftijd, psychische problemen op latere leeftijd (Reef et al., 2010). Effectieve en vroege interventies op jonge leeftijd zijn dus noodzakelijk en goed kinder \& jeugd psychiatrisch beleid zou een vanzelfsprekendheid moeten zijn. Echter, er bestaat in slechts $7 \%$ van de landen wereldwijd een specifiek kinder en jeugd psychiatrisch beleid (Shatkin et al., 2004). In de Verenigde Staten wordt slechts $11 \%$ van het totale overheidsbudget voor psychiatrie en verslaving aan mensen onder de 18 jaar uitgegeven, 89\% gaat naar de rest (Costello et al., 2005). Om het nog erger te maken: zowel in Australie en Engeland laat onderzoek zien, dat de groep die het meeste last heeft van psychische stoornissen, namelijk jeugdigen, de minste toegang tot zorg hebben. Er is sprake van onderconsumptie in deze levensfase. Gegevens van GGZ Nederland suggereren dat deze onderconsumptie ook geldt voor de Nederlandse jeugdigen. 
Er lijkt dus sprake van een gap tussen zorgbehoefte en zorg consumptie in deze levensfase. Lange termijn gevolgen van psychische stoornissen worden verergerd door te laat of geen hulp zoeken (de Giralomo et al., 2012). Wat weerhoudt jeugdigen er nu van hulp voor psychische problemen te zoeken? Dit is recent onderzocht door middel van een telefonische enquete in Australie onder ruim 3000 jeugdigen. De resultaten lieten zien dat vooral schaamte en verlegenheid een belemmering vormde voor het vragen van hulp en slechts $10 \%$ gaf aan zeker professionele hulp te zoeken als ze problemen zouden hebben, wat een zorgelijke bevinding is (Yap et al., 2012). We moeten dus investeren in toegankelijke, jeugdvriendelijke psychische hulpverlening die past bij levensfase en levensstijl en dit zou gezien deze cijfers hoog op de politieke agenda moeten staan.

\section{De $2^{\mathrm{e}}$ gap}

ledereen die voor zijn $18^{\mathrm{e}}$ verjaardag hulp vraagt voor psychische problemen, komt bij de kinder \& jeugd psychiatrie terecht. Zodra je 18 jaar bent kom je voor psychische problemen terecht bij de volwassen psychiatrie. In de praktijk is het onderscheid tussen deze 2 sectoren groter dan slechts een verschil in kalenderleeftijd. Als 17 jarige, wordt je in ieder geval uitgenodigd samen met je ouders, die ook gevraagd worden om vragenlijsten over jouw gedrag in te vullen. Deze vragenlijsten hebben vooral betrekking op stoornissen die in de DSM IV geclassificeerd worden in het hoofdstuk "stoornissen die meestal op zuigelingenleeftijd, kinderleeftijd of in de adolescentie gediagnosticeerd worden". Klop je echter een dag na je $18^{\mathrm{e}}$ verjaardag aan voor psychische hulp, dan worden je normaal gesproken alleen uitgenodigd en zelf gevraagd vragenlijsten over jezelf in te vullen. Deze vragenlijsten hebben vooral betrekking hebben op stoornissen die niet staan in het hoofdstuk van "stoornissen die meestal op zuigelingenleeftijd, kinderleeftijd of in de adolescentie gediagnosticeerd worden". Er lijkt dus niet alleen een formele scheiding aanwezig tussen kinder en jeugd en volwassen psychiatrie op basis van leeftijd, ook inhoudelijk is deze scheiding goed zichtbaar door verschillen in benadering, aandachtsgebieden en gebruikte instrumenten voor diagnostiek en effectmeting, die niet goed op elkaar aansluiten. Dit staat continuiteit van zorg in de weg juist op een cruciaal moment in het leven. Hoe gaat dat nu als onze 17 jarige patient autisme blijkt te hebben en na zijn $18^{\mathrm{e}}$ verjaardag over moet stappen naar de volwassen psychiatrie? De afgelopen jaren ben ik regelmatig benaderd door wanhopige kinderpsychiaters die hun patienten van 18 jaar en ouder "niet kwijt" konden bij de volwassen psychiatrie. Meestal ging het hier om jeugdigen met autisme, ADHD of een verstandelijke beperking. Aangezien de reguliere volwassen psychiatrie hier onvoldoende op ingericht is, blijven de deuren voor deze jeugdigen vaak gesloten waardoor ze buiten in de vrieskou blijven staan. Inmiddels realiseren we ons dat deze stoornissen niet ophouden bij het bereiken van de 18-jarige leeftijd en is er in de volwassen psychiatrie de afgelopen jaren in een aantal centra een goede expertise opgebouwd op het gebied van ADHD en autisme spectrum stoornissen. In de dagelijkse praktijk is een vloeiende overgang van kinder- en jeugd naar volwassen psychiatrie op 18-jarige leeftijd echter helemaal niet vanzelfsprekend. 
Niet zelden wordt een jeugdige als hij 18 jaar wordt naar een compleet andere organisatie of locatie met nieuwe gezichten verwezen. Dit is geen eenvoudige zaak als je autisme hebt, en elke verandering moeilijk is; of als je achterdochtig bent, en niet zo snel van vertrouwen. Wat nu als een 16 jarige jongedame zich terugtrekt en slechtere cijfers op school haalt? Haar ouders weten zich geen raad en maken zich ernstige zorgen. Dit zouden voortekenen van een psychose kunnen zijn. De afgelopen jaren ben ik ook regelmatig benaderd door kinder en jeugd psychiaters met het verzoek hun minderjarige patienten over te nemen vanwege verdenking op een psychotische ontwikkeling omdat zij zelf vonden dat ze onvoldoende expertise op dit gebied hadden. Terwijl vroeger gedacht werd dat psychose een stoornis was welke zich meestal voor het eerst op volwassen leeftijd manifesteerde, weten we inmiddels dat de voortekenen van psychose al vaak ontstaan rond 15 jarige leeftijd en zich dus zullen presenteren bij de kinder en jeugd psychiater.

Wat het extra lastig maakt is dat deze voortekenen vaak moeilijk als zodanig te herkennen zijn, aangezien deze vaak bestaan uit aspecifieke symptomen als angst of somberheid (Cohen et al., 2012), of zoals bij onze 16 jarige patiente slechtere schoolprestaties of terugtrek gedrag. Deze voortekenen worden dus makkelijk gemist als men er niet specifiek naar op zoek gaat. Aangezien een psychotische stoornis een van de ernstigste stoornissen is in de psychiatrie, en de prognose verbeterd kan worden wanneer men er vroeg bij is, is het cruciaal om mensen met voortekenen van een psychose op te sporen en te monitoren. Recent is aangetoond dat mensen met voortekenen van een psychose die cognitieve gedragstherapie krijgen aangeboden, minder vaak psychotisch worden en vaker van hun klachten af komen (van der Gaag et al., 2012). Het is dus belangrijk dat kinder en jeugd psychiaters al starten met opsporen van psychose en gebruik maken van geschikte screenings en meetinstrumenten. Gelukkig wordt er binnen de kinder \& jeugd psychiatrie ook steeds meer aandacht besteed aan het opsporen van psychose door specifieke vroeg detectie programma's welke momenteel in een aantal delen van Nederland al geimplementeerd worden. Dus ook op het gebied van psychose is een goede samenwerking tussen de kinder \& jeugd en volwassen psychiatrie essentieel om te zorgen dat de aansluiting en continuiteit zo optimaal mogelijk is. Helaas is deze vaak niet optimaal. Een recente studie uit Engeland van een groep die al wat langer onderzoek doet op het gebied van transitiepsychiatrie, liet zien dat minder dan $\mathbf{5 \%}$ van de transities van kinder en jeugd naar volwassen psychiatrie naar tevredenheid verliep (Singh et al., 2010). Samenvattend kunnen we dus concluderen dat de periode rondom het $18^{\mathrm{e}}$ levensjaar een van de meest kwetsbare fases is voor psychische problemen, maar dat tegelijkertijd ook het zorgsysteem dan op zijn kwetsbaarst is, terwijl het eigenlijk dan op zijn sterkst zou moeten zijn. Des te onbegrijpelijker is het dat deze gap door voorgenomen beleid in Den-Haag nog groter gemaakt dreigt te worden door het voornemen de kinder en jeugd psychiatrie naar de gemeentes over te hevelen en zo nog verder te verwijderen van de volwassen psychiatrie. 


\section{De $3^{\mathrm{e}}$ gap}

Ongeveer vierhonderd jaar geleden omschreef William Shakespeare jeugdigen als volgt in zijn werk "a Winter's Tale";

I would there were no age between sixteen and three-and-twenty, or that youth would sleep out the rest; for there is nothing in the between but getting wenches with child, wronging the ancientry, stealing, fighting--Hark you now! Would any but these boiled brains of nineteen and two-and-twenty hunt this weather? (III.iii.58-64)

Het komt er op neer, dat jeugdigen door Shakespeare werden beschreven als lastige jonge individuen die impulsief, soms gevaarlijk gedrag vertoonden. Ook heden ten dage zijn we nog wel eens geneigd om onze jeugd negatief af te schilderen; de slogan "de jeugd van tegenwoordig" is veelzeggend. Kort samengevat komt dit beeld neer op ongehoorzame, luie, niet communicatieve en roekeloze individuen. Dit natuurlijk vooral in de beleving van ouders, opvoeders, leraren, en misschien soms ook wel wij hulpverleners? De vraag is of dit beeld wel helemaal terecht is? Begrijpen we onze jeugdigen voldoende en weten we eigenlijk wat voor veranderingen er precies plaatsvinden in hun hersenen? In tegenstelling tot afbakening door de wettelijke kaders, laten de biologische veranderingen die tijdens de jeugd plaatsvinden zich niet door middel van leeftijdsgrenzen afbakenen, en kunnen we dus niet zeggen "dan en dan zijn de hersenen klaar ". Er is lang gedacht dat de hersenen volgroeid waren met het bereiken van 5 jarige leeftijd. Hersenen zijn namelijk bij de geboorte relatief groot. Het hersenvolume van een pasgeboren baby bedraagt ongeveer de helft van het volume op volwassen leeftijd; bij een 2 jarige peuter is dit ongeveer $80 \%$ en de hersenen van een 5 jarige kleuter beslaan al 95\% van het volume van zijn of haar hersenen op volwassen leeftijd. Als we alleen naar de schedelomtrek kijken, en dit was vroeger de standaard methode om hersenvolume vast te stellen, kan men stellen dat de hersenen van een 5 jarige inderdaad bijna volwassen proporties heeft bereikt. Door de introductie van beeldvormende technieken zoals MRI scans zijn nu we in staat om in-vivo de hersenstructuren en functies nauwkeurig in beeld te brengen en is onze kennis over de normale ontwikkeling van de hersenen de afgelopen decennia in een stroomversnelling gekomen. Hierdoor hebben we inmiddels veel nieuwe inzichten gekregen over hoe de hersenen zich vanaf de geboorte ontwikkelen. Zo weten we bijvoorbeeld dat onder normale omstandigheden het totale hersenvolume inderdaad niet heel veel meer veranderd vanaf de kindertijd, maar met een inhoud van ongeveer 1,2 liter redelijk stabiel blijft tot ongeveer $30^{\mathrm{e}}$ jarige leeftijd. Echter dit betekent niet dat de hersenen vanaf de kleuterleeftijd tot stilstand zijn gekomen. We weten, nu we de structuur van de hersenen zo nauwkeurig in beeld kunnen brengen, dat de hersenen intern continu aan het reorganiseren zijn gedurende de levensloop, maar met name 
tijdens de jeugd. Deze interne reorganisatie, zijn vooral veranderingen in grijze en witte stof en deze vinden onder normale omstandigheden netjes op elkaar afgestemd plaats. Ze zijn als het ware voorgeprogrammeerd. Het totale volume van onze "grijze cellen" neemt vanaf kinderleeftijd langzaam af.

Deze voorgeprogrammeerde afname van grijze stof wordt ook wel het snoeiproces, of pruning genoemd. Hierbij worden de verbindingen tussen de hersencellen gesnoeid. Dit gebeurt volgens het "use it or loose it" principe. Dit betekent dat als je een deel van de hersenen weinig gebruikt, hier de meeste verbindingen worden afgebroken. Dat betekent dus ook dat de gebieden in hersenen die veel gebruikt of getraind worden de verbindingen daar extra hecht zullen zijn. Dus hoe de hersenen zich zullen ontwikkelen wordt mede bepaald door wat er zich in de omgeving afspeelt. Naast de grijze stof, bestaan de hersenen uit witte stof. Deze is opgebouwd uit lange uitlopers van hersencellen die voorzien zijn van een witte isolatie laag, die zo de grijze cellen met elkaar verbindt. De witte stof fungeert als een soort snelwegen die de grijze knooppunten van de hersenen met elkaar verbinden en er zo voor zorgt dat communicatie tussen grijze cellen snel en efficient gebeurt. Het blijkt dat de kwaliteit van deze witte stof verbindingen samenhangt met intelligentie en efficientie van de hersenen (van den Heuvel et al., 2009). Terwijl het totale volume van de grijze stof vanaf kinderleeftijd gedurende de jeugd met ongeveer $15 \%$ afneemt, neemt ongeveer tegelijkertijd het totale volume van de witte stof juist met dezelfde $15 \%$ toe door de aanleg van deze witte "snelwegen". Dit proces gaat door tot ongeveer 25 tot 30- jarige leeftijd en vindt gefaseerd plaats, waarbij de voorste delen van de hersenen, de frontaal kwabben, het laatst aan de beurt zijn (Johnson SB et al., 2009). Kortom het netwerk van snelwegen in de hersenen is op 18 jarige leeftijd nog lang niet voltooid. Deze nieuwe kennis helpt ons om onze jeugdigen en hun kwetsbaarheid voor psychopathologie beter te begrijpen. Bijvoorbeeld bij autisme en psychose is de regulatie van het snoeiproces van de grijze cellen verstoord en zijn de witte snelwegen op sommige locaties niet goed ontwikkeld.

Er zijn twee domeinen van de hersenen die ik hier wil noemen die sterke biologische veranderingen ondergaan tijdens de jeugd. Allereerst het beloningscircuit van de hersenen. Het beloningssysteem kan men in de hersenen goed onderzoeken met behulp van functionele MRI.

Terwijl je in de hersenscanner ligt voer je een taak uit waarbij geld verdiend of verloren kan worden; een soort gokken ten behoeve van de wetenschap. Uit functionele MRI studies van de hersenen blijkt dat jeugdigen extra gevoelig te zijn voor beloning, veel meer dan volwassenen en veel meer dan jongere kinderen. Jeugdigen zijn geneigd keuzes te maken voor dingen die een directe, beloning opleveren, ook al zijn uiteindelijk de lange termijn consequenties negatief (Crone \& Dahl, 2012). Dit in tegenstelling tot volwassenen voor wie het vooruitzicht op een beloning eigenlijk belangrijker is dan het krijgen van de beloning zelf. Het beloningssysteem wordt gereguleerd door dopamine (Da Silva Alves et al., 2011). Deze extra gevoeligheid van het beloningssysteem bij jeugdigen blijkt samen te hangen met het 
verhoogde dopamine signaal in het limbische systeem van de hersenen, het deel van de hersenen wat betrokken is bij emotie, genot en plezier. Vanuit dieronderzoek weten we dat de activiteit van het dopamine systeem groter is tijdens de jeugd dan welke andere levensfase dan ook (Sisk \& Zehr, 2005). Dus het gedrag van jeugdigen hangt sterker dan bij volwassen samen met motivatie en beloning onder andere door tijdelijke veranderingen van het dopamine systeem. Ze willen bv best hun kamer opruimen als er maar zicht is op een voor hen interessante beloning. Het beloningssysteem vormt op dit moment een enorm aandachtsgebied binnen de psychiatrie aangezien het een belangrijke rol blijkt te spelen bij diverse psychiatrische stoornissen die zich manifesteren tijdens de jeugd zoals bv psychose, stemmingsstoornissen, eetstoornissen of verslaving.

Naast het beloningscircuit, is gebrek aan controle kenmerkend voor de jeugdige. Het impulsieve, soms risicovolle gedrag wat hieruit voort kan vloeien werd toe nu toe steeds toegeschreven aan de relatief late rijping van de voorste delen van hersenen waar de aanleg van de witte "snelwegen" nog niet is voltooid. De frontaal kwabben zijn nu juist de delen van de hersenen waar onder andere planning, impuls controle, en werkgeheugen gereguleerd worden, en ze zijn dus een soort CEO van het brein. Er is tot recent gedacht dat het achterblijven van de ontwikkeling van de frontaal kwabben ten opzichte van bv het limbische systeem van de hersenen, de zogenaamde "maturational gap", verantwoordelijk was voor roekeloos en impulsief gedrag tijdens de jeugd. Ze zouden er dus niets aan kunnen doen dat ze zich zo gedragen. Toch nuanceren recente inzichten deze theorie enigszins. Waarbij we tot nog toe spraken over "onrijp" brein blijkt dat nu het veel optimistischer klinkend "flexibel brein" te zijn. Het blijkt dat het jeugdige brein niet erg actief, of een beetje lui, is waar het gaat om "standaard of automatische taken" maar extra actief, of gemotiveerd is, als het gaat om zaken die betrekking hebben op creativiteit, nieuwe prikkels uit de omgeving, en sociale relaties. Kennelijk gebruiken jeugdigen hun frontaal kwabben voor andere problemen en ander soort beslissingen dan jongere kinderen en volwassenen. Met name de emotionele en sociale omgeving heeft tijdens de jeugd invloed op keuzes en gedrag. Bijvoorbeeld, uit functionele MRI studies blijkt dat risicovol gedrag vaker voorkomt als er leeftijdsgenoten bij zijn, in vergelijking als wanneer men alleen is, terwijl het bij volwassenen niet uit blijkt te maken of er anderen bij zijn of niet. Dus bevindingen van hersenonderzoek benadrukken nog eens hoe cruciaal deze levensfase is. De sociale en emotionele context kunnen juist in deze fase heel bepalend zijn voor hoe iemand zich verder ontwikkelt. "Positieve" omgevingsfactoren zoals bv veilige gezinssituaties of "negatieve" omgevingsfactoren zoals bv cannabis gebruik kunnen al dan niet in combinatie met een erfelijke kwetsbaarheid er mede toe bijdragen of iemand wel of niet een psychiatrische ziekte ontwikkelt.

De uitdagingen en veranderingen in onze huidige maatschappij brengt met zich mee dat het brein van jeugdigen zich op een andere manier ontwikkelt dan het brein van de huidige volwassenen. De pubertijd van mijn ouders begon met de introductie van televisie, mijn 
pubertijd bestond uit video en cd spelers, terwijl er nog geen mobiele telefoon, computers, laat staan internet was. Mijn zoon groeit op met de iPad, sociale media, en Apps. Dat betekent dat het brein van de jeugdige van nu aan hele andere prikkels wordt blootgesteld, dan bijvoorbeeld 20 jaar geleden. Onze jeugdigen groeien op in een maatschappij, die veel complexer is en steeds meer eisen aan ze stelt. Dus het zich nog ontwikkelende brein van een jeugdige moet flexibel zijn en zich kunnen aanpassen aan een steeds veranderende omgeving. Helaas wordt ook op het terrein van het wetenschappelijk onderzoek het beleid door leeftijdsgrenzen bepaald, terwijl er inmiddels voldoende bewijs is dat op 18 jarige leeftijd de hersenen nog midden in hun interne reorganisatie proces zitten. Veel studies onderzoeken of mensen onder de 18 jaar gebruikmakend van kinder en jeugd meetinstrumenten, of mensen boven de 18 jaar, gebruikmakend van andere, volwassen meetinstrumenten.

Het gevolg is dat de resultaten van wetenschappelijk onderzoek door deze scheiding vaak niet goed op elkaar aansluiten waardoor er een gap is in onze kennis op het gebied van ontwikkeling van de hersenen tijdens een fase waarin veel psychiatrische ziektebeelden zich voor het eerst manifesteren en waar we juist deze kennis hard nodig hebben. Het is dus cruciaal om de levensloop als een continuum te onderzoeken en dus ook in het wetenschappelijk onderzoek de grens van18 jaar los te laten.

\section{Toekomst}

Ik denk dat ik u inmiddels duidelijk heb gemaakt dat ik meer aandacht zou willen voor het geestelijk welbevinden van onze jeugdigen en dat we de zwakke schakels in ons zorgstelsel in deze levensfase moeten versterken. Maar hoe kunnen we deze doelgroep bereiken? Hoe kunnen we de drempel verlagen voor het zoeken van hulp? Om continuïteit van zorg te bevorderen in een levensfase waarin psychische kwetsbaarheid op zijn grootst is, zou het goed zijn om speciale "jeugd" psychiatrische programma's op te zetten.

De jeugdigen zouden zelf betrokken moeten worden bij het inrichten van zo'n programma. Leeftijdsfase specifieke interventies, laagdrempeligheid, sociale en educatieve interventies zouden hierin een belangrijke plaats innemen. Evenals focus op ontwikkelingsleeftijd in plaats van kalenderleeftijd, flexibiliteit van hulpverleners, preventie van sociale isolatie. Maar wanneer is psychiatrische hulp nodig? Over het algemeen ga je naar de dokter als je ziek bent. In de psychiatrie is de definitie van ziek zijn niet altijd zo voor de hand liggend als bij andere medisch specialismen.

Wij psychiaters zijn hiervoor namelijk afhankelijk van de zogenaamde DSM-IV, binnenkort DSM V, een boekje waarin door vooral Amerikaanse psychiaters is afgesproken aan welke criteria iemand moet voldoen voordat hij of zij een bepaalde psychiatrische ziekte heeft. Zo'n boekje is natuurlijk niet zaligmakend. De diagnostiek is gebaseerd op interviews waarbij de nodige inter-individuele variatie optreedt. Het zorgt er tevens voor dat mensen in hokjes, categorieen, geplaatst worden, waar je als je daar eenmaal in een terecht komt bijna niet meer uitkomt, zoals bv het geval is voor schizofrenie. Een ander bijkomend probleem is dat 
verschillende psychiatrische stoornissen vaak in combinatie voorkomen en er een grote mate van overlap in onderliggende kwetsbaarheid en presenterende symptomen. Met name tijdens de jeugd, is het soms moeilijk vast te stellen welk ziektebeeld zich uiteindelijk gaat ontwikkelen. Van de mensen met voortekenen van een psychose bijvoorbeeld blijkt $40 \%$ tegelijkertijd ook een depressieve stoornis te hebben (Fusar-Poli et al., 2012), is na 2 jaar15\% psychotisch geworden (Fusar-Poli et al., 2012) en van de mensen die niet psychotisch geworden zijn na 3 jaar, heeft drie kwart uberhaupt geen voortekenen meer (Velthorst et al., 2011). Dit geeft aan hoe moeilijk het is om in deze leeftijdsfase vast te stellen wat er precies aan de hand is en dat het diagnostisch nog alle kanten op kan gaan, ook de kant van geen diagnose. Gezien de beperkingen van ons huidige diagnostisch systeem, gaan er steeds meer stemmen op om ons huidige diagnostisch classificatiesysteem te hervormen.

Een benadering hiervoor is stagering. Ook hier lopen wij psychiaters achter ten opzichte van onze somatische collega's. Vele andere medische specialismen bv de oncologen hebben stagering al jaren geleden geintroduceerd. Hierbij wordt elk stadium van een ziekte bv huidkanker, gekoppeld aan bijbehorende klinische en biologische kenmerken. Op een zelfde manier kun je met dit systeem bij mensen met een verhoogd risico of een beginnende psychiatrische stoornis komen tot een beter risicoprofiel, vroeger ingrijpen en meer "gefinetunede' behandelstrategieën. Dit concept begint inmiddels ook door te dringen tot de psychiatrie. Aangezien voortekenen en beginfases van psychiatrische ziektebeelden vaak jeugdigen betreffen, zal preventie, vroege opsporing en stagering zich bij uitstek afspelen op het grensvlak van kinder en jeugd en volwassen psychiatrie.

\section{Patientenzorg}

Wat ga ik de komende jaren doe op het gebied van de patientenzorg in Zuid-Limburg? Ik zal me inzetten om de samenwerking tussen de kinder \& jeugd en volwassen psychiatrie te intensiveren en ernaar streven om jeugdigen zorg aan te bieden die past bij de levensfase van deze doelgroep, en bij de huidige tijdsgeest. Allereerst zal ik dat doen bij Virenze, een landelijke GGZ instelling. Ik ben verheugd dat Virenze naast Infant Mental Health, adolescentenzorg als speerpunt gekozen heeft. Een aantal Virenze vestigingen buiten de provincie Limburg, zijn al gestart met jeugdpoli's welke de leeftijdsgrens van 18 jaar hebben losgelaten en specifiek voor 15-24 jarigen zijn ingericht. In Maastricht vinden de voorbereidingen voor een dergelijke jeugdpoli ook al plaats. Ik kijk uit naar de verdere ontwikkeling hiervan. Ten tweede zal ik me met veel plezier blijven inzetten voor zwakbegaafde jeugdigen van 15 tot 24 jaar met co-morbide psychische problemen die langdurig verblijven bij de Koraalgroep. Het gaat hier om jeugdigen die vaak een zeer slechte start in het leven hebben gehad met soms heel weinig perspectief. Het is goed te ervaren dat in deze behandelsetting, die niet onderdeel uitmaakt van de GGZ en ook een andere financieringsstructuur kent, er geen schot geplaatst wordt bij 18 jaar. Hier wordt in de eerste plaats per individuele patient gekeken naar de mate van ontwikkeling en veerkracht en niet naar biologische kalenderleeftijd. Tenslotte zal ik me nog op een heel ander terrein met de 
transitiepsychiatrie bezighouden. Het betreft hier de patiënten met 22q11 deletie syndroom, een patientengroep die ik al ruim 15 jaar een warm hart toedraag. Deze unieke groep mensen worden geboren met een deletie van de lange arm op chromosoom 22. Ze hebben vaak veel lichamelijke problemen, maar ook een verstandelijke beperking en een heel scala aan psychiatrische problemen die zich manifesteren gedurende de levensloop in drie kwart van de patienten. Aangezien de levensverwachting van deze groep mensen de laatste decennia enorm is toegenomen, is ook de vraag naar multidisciplinaire zorg gedurende de levensloop gerezen. Mensen met een verstandelijke beperking hebben een verhoogd risico op het ontwikkelen van psychische problemen inclusief een tot $5 x$ grotere kans op het ontwikkelen van een psychose. Mensen met 22q11 deletie syndroom hebben zelfs een 25x hogere kans psychotisch te worden. Reeds jaren bestaan er zogenaamde "transitie poli's" voor mensen met een verstandelijke beperking en genetische syndromen. De psychiater speelt in deze transitie poli's een belangrijke rol. Deze poli's zijn multidisciplinair, en flexibel. Gelukkig heeft het AZM onder leiding van Connie Stumpel een uitgebreide expertise opgebouwd met transitiepoli's voor mensen met genetische syndromen en ik verheug me om samen met haar team in het AZM de transitiepoli voor mensen met 22q11 deletie syndroom te ontwikkelen. Volgende maand gaan we van start met een volgeboekt spreekuur.

\section{Onderwijs}

Ook in het onderwijs is de gap tussen kinder- en jeugd en volwassen psychiatrie zichtbaar. Een arts die in Nederland is opgeleid als psychiater, kreeg tot voor kort automatisch de opleiding tot volwassen psychiater aangeboden waarbij ervaring op doen in de kinder en jeugdpsychiatrie niet vanzelfsprekend was. Dit betekent dat er bij een flink aantal psychiaters onbekendheid is met het vakgebied kinder en jeugd psychiatrie. Ditzelfde geldt voor de verstandelijke gehandicaptenpsychiatrie. Deze onbekendheid zou er mede toe bij kunnen dragen dat toenadering tussen de kinder en jeugd psychiatrie en volwassenen psychiatrie niet vanzelfsprekend is. Ik zou het een goede zaak vinden als er tijdens de basisopleiding structureel aandacht zou komen voor de psychiatrie gedurende de hele levensloop. Met name de jeugd als kwetsbare fase zou tijdens de basis opleiding een aparte plek verdienen. Ik zet me hier graag voor in. Gezien de beperkte validiteit van onze huidige categorale benadering van psychiatrische stoornissen is het denk ik van groot belang om in het onderwijs aandacht te besteden aan centrale concepten van psychiatrische functiestoornissen, zoals bv cognitie, beloningsystemen, emotie en impulsregulatie. Ook dit is relevant in de context van alle biologische veranderingen die er spelen in de hersenen tijdens de jeugd. Dit onderwijs heeft consequenties voor de toekomstige zorg maar is ook relevant voor het stimuleren en motiveren van aanstaande collega's om betrokken te raken bij zorg en onderzoek in de psychiatrie.

\section{Onderzoeksagenda}


Wat zal ik de komende jaren op onderzoeksgebied gaan doen? Mijn onderzoek zal zich vooral op de jeugdige populatie richten.

Ten eerste zal ik me bezighouden met fundamenteel en experimenteel onderzoek bij jeugdigen. Ik ben van huis uit een biologisch onderzoeker en dus altijd nieuwsgierig naar onderliggende mechanismen van psychopathologie, waarvoor ik vooral graag gebruik maak van neuroimaging technieken.

Samen met Jim van Os en Inez Myin-Germeys ga ik onderzoek doen naar het effect van selfmanagement training bij jeugdigen met sub-klinische psychische klachten. Dit project, wat mogelijk gemaakt wordt door de stichting Wijerhorst, heeft als doel het voorkomen of uitstellen van ernstige, klinische psychopathologie bij jeugdigen gebruikmakend van nietmedicamenteuze interventies. Het is een experimentele studie waar in totaal ruim 200 jeugdigen uit deze regio aan mee zullen doen. Het project zal zich richten op 3 symptoomdimensies, te weten depressieve, angst en psychotische symptomen. We willen onderzoeken of deze interventie, de "acceptance \& commitment" training, leidt to een afname van klachten. Met behulp van de "experienced sampling methode" een soort electronisch dagboek, die door de Universiteit van Maastricht is ontwikkeld meten we gedurende een paar weken dagelijkse de ervaringen van de studie deelnemers. Het onderzoek bevat een neuroimaging deel wat zal plaatsvinden in het splinternieuwe neuroimaging centrum Brains Unlimited in Maastricht. Naast het in kaart brengen van de hersenstructuur en hersenactiviteit in rust gaan we gaan ook onderzoeken wat de relatie is tussen psychische klachten en hersenactiviteit wanneer het beloningssysteem geactiveerd wordt en er angst conditionering plaats vindt.

Vervolgens zal ik in een ander project onderzoek gaan doen naar het onderliggend mechanisme van geheugen en aandachtsproblemen bij jeugdigen met een beginnende psychose. Waarom kiezen we voor cognitieve symptomen? We weten inmiddels dat bij een beginnende psychose cognitieve en sociale problemen vaak eerder optreden dan bijvoorbeeld wanen of hallucinaties. Een eerste signaal van een psychose kan zijn dat het op school slechter gaat of dat jeugdigen zich terug gaan trekken. Het blijkt deze geheugen, en aandachtsproblemen bij een psychose het meest invaliderend zijn en de grootste voorspellers zijn voor toekomstig functioneren. Ze dragen bij aan school uitval en arbeidsongeschiktheid. Uit een recent onderzoek uitgevoerd door het Trimbos Instituut waarbij jongeren met een eerste psychose ondervraagd werden naar kwaliteit van leven en toekomstplannen bleek dat jongeren die al een psychose hadden doorgemaakt de kwaliteit van leven lager te zijn dan mensen zonder psychose (Trimbos Instituut, 2012). De jongeren gaven zelf aan dat ze meer behoefte hadden aan training van geheugen en aandacht. Trainingen die op lange termijn effectief zijn nog niet beschikbaar. Helaas zijn het ook juist deze symptomen die we nog niet goed kunnen behandelen met de huidige medicatie. 
Verbetering van geheugen en aandacht bij mensen met een psychose heeft nu de volle aandacht van de internationale psychose gemeenschap. Daarom vindt er nu ook een enorme zoektocht plaats naar nieuwe behandelingsmethoden die geheugen en aandacht bij psychose kan verbeteren. Na jarenlang enthousiast het dopamine systeem onderzocht te hebben ga ik in dit onderzoek switchen naar acetylcholine, een andere neurotransmitter waarvan bekend is dat deze een grote rol speelt bij geheugen en aandacht. Samen met Jan Booij van de afdeling Nucleaire Geneeskunde van het AMC zal ik met behulp van SPECT en functionele MRI onderzoeken of afwijkingen in het cholinerge neurotransmittersysteem bij jonge mensen met een psychose verantwoordelijk zijn voor hun geheugen en aandachts problemen. De resultaten van dit onderzoek zullen bij dragen aan nieuwe kennis en inzichten en misschien tot nieuwe behandelingsmogelijkheden voor deze doelgroep kunnen leiden. Als we er uiteindelijk voor zouden kunnen zorgen dat deze jongeren op school blijven of weer aan het werk kunnen doordat ze minder last hebben van geheugen en concentratie problemen hebben zou dit een enorme mijlpaal zijn.

De tweede onderzoekslijn zal richt meer richten op onderzoek in de klinische praktijk bij Mondriaan en Virenze. Om te beginnen ga ik me richten op onderzoek naar nieuwe behandelingen voor jeugdigen die aansluiten bij de levensfase en de huidige tijdsgeest. Samen met Goedele Meeus gaan we de effecten meten van een nieuwe behandelingsmethode die door Mondriaan wordt aangeboden aan jeugdigen met autisme. Door middel van muziektherapeutische bandcoaching (MTB) spelen jeugdigen met autisme gezamenlijk in een band. Gedurende 1-2 jaar zullen ze wekelijks onder begeleiding van een muziektherapeute gaan spelen met als doel de sociale en communicatieve vaardigheden te verbeteren. Met routine klinische meetinstrumenten worden sociale vaardigheden, gedrag en andere symptomen gemeten.

Daarnaast ga ik bij Mondriaan samen met Goedele Meeus bij jongeren met ADHD onderzoeken of aandacht, concentratie en planningsvermogen door middel van een therapeutisch spel, de "serious healseeker game", verbeterd kan worden. Na training en instructies op de poli is het de bedoeling dat de jongeren dagelijks in de thuissituatie oefenen met het spel. Op reguliere meetmomenten wordt aandacht, concentratie en planningsvermogen gemeten.

Met de introductie van 2 jeugd FACT teams bij Mondriaan ga ik samen met Emily Chatrou starten met het meten van het effect van de voor deze regio nieuwe behandelvorm voor jeugdigen met complexe psychiatrische problematiek. Screening op hoog risico symptomen voor psychose zal standaard plaatsvinden bij aanvang van de behandeling. Zo kunnen we bepalen hoe vaak voortekenen van een psychose bij jeugdigen in deze regio voorkomen.

Bij Virenze zal onderzocht worden wat het effect van 5 jaar Infant Mental Health heeft opgeleverd. Er zijn namelijk steeds meer aanwijzingen dat vroege interventie psychische 
problemen op latere leeftijd kan voorkomen. Daarnaast willen we met het van start gaan van de jeugd poli ook hier systematisch gaan screenen op voortekenen van psychose.

Tenslotte zal ik me richten op onderzoek naar genetische syndromen en verstandelijke beperkingen. Dit zal vooral betekenen het voortzetten van mijn onderzoeksactiviteiten samen met Erik Boot op het gebied van 22q11 deletiesyndroom. Zoals ik al noemde, heb ik de afgelopen 15 jaar ongeveer 150 patienten met dit complexe, maar vanuit wetenschappelijk oogpunt bezien zeer boeiende syndroom onderzocht. Deze erfelijke afwijking is een van de grootste genetische risicofactoren voor het ontwikkelen van psychose. Eigenlijk vormt deze populatie een uniek humaan knock-out model, omdat van een 30-50 tal bekende genen, de dosis van het gen gereduceerd is en de gevolgen hiervan op gedrag en brein goed onderzocht kunnen worden.

Onderzoek op dit terrein heeft inmiddels geleid tot een internationaal consortium, waarin ruim 20 landen vanuit diverse disciplines op een hele prettige manier met elkaar samenwerken. Maastricht en Utrecht maken samen deel uit van dit internationale consortium waarin we gezamenlijk ruim 2000 patienten gezien hebben en in kaart gebracht hebben. De komende jaren gaan we kijken hoe genetische variaties bij dit syndroom het spectrum aan psychiatrische ziekte beelden kunnen verklaren. Tenslotte, treedt ik samen met Paul Curfs op als promotor van Rens Evers die in samenwerking met De Koraal Groep hier in Maastricht onderzoek doet naar cognitieve achteruitgang bij mensen met 22q11 deletie syndroom.

\section{Dankwoord}

Inmiddels ben ik aangeland bij het einde van deze rede. Ik heb gepleit voor het weghalen van de schotten die op dit moment een goede aansluiting tussen de vakgebieden kinder en jeugd en volwassen psychiatrie in de weg staan. Tevens pleit ik voor specifieke jeugdvriendelijke, laagdrempelige zorgprogramma's die schot overstijgend zijn en aansluiten bij de levensfase. Ik hoop dat we als psychiaters in de toekomst flexibeler om kunnen gaan met deze doelgroep en ook open staan voor elkaars patienten in plaats van deuren dicht te houden. Dit is absoluut noodzakelijk als we de nieuwste ontwikkelingen die op dit moment in de psychiatrie in Nederland gaande zijn zoals preventie, vroeg detectie, stagering succesvol willen implementeren. Om dit mogelijk te maken zal de transitiepsychiatrie de brug moeten slaan tussen kinder en jeugd psychiatrie enerzijds en de volwassen psychiatrie anderzijds. Als je zoals ik op meerdere plekken tegelijk werkzaam bent, en ook nog af en toe een keer verhuist dan zijn er heel veel mensen die je dankbaar bent voor een geweldige samenwerking. Helaas kan ik niet iedereen persoonlijk noemen, dus bij deze hartelijk dank! Een aantal mensen wil ik uiteraard wel persoonlijk bedanken. Allereerst dank ik het College van Bestuur van de Universiteit van Maastricht, en de Raad van Bestuur van het AZM voor het in mij gestelde vertrouwen. Daarnaast ben ik de Raad van Bestuur van Virenze en de Raad van Bestuur en divisie Kinder en Jeugdpsychiatrie van Mondriaan, zeer dankbaar voor het mogelijk maken van deze leerstoel. Jim van Os, beste Jim, achter de schermen ben jij het 
brein achter deze zo uitdagende leerstoel. Ik ben enorm onder de indruk van de vele ballen die je moeiteloos in de lucht lijkt te houden. Jij hebt hier de Nederlandse versie van de Institute of Psychiatry gecreëerd en het is een eer er te mogen werken. Ik dank mijn promotoren Don Linszen en Declan Murphy. Declan's praktische "do's and don'ts" voor het bedrijven van de wetenschappelijke topsport komen me tot op de dag van vandaag nog regelmatig van pas. Jan Booij, beste Jan, jij bent gedurende mijn 10 jaar bij het AMC een constant klankbord geweest. Ik ben heel blij dat we onze samenwerking met het Vidi project kunnen voortzetten. Inez Myin-Germeys, beste Inez, ik ben je dankbaar voor het warme welkom op jouw afdeling. De motiverende en stimulerende sfeer in combinatie met groot sociaal kapitaal maakt dat het een feest is om er te werken.

Tenslotte het thuisfront. Ik dank mijn ouders. Mam gelukkig ben je alweer voldoende hersteld om hier vandaag bij te kunnen zijn. Tom, helaas laten de stricte leeftijdsgrenzen van het universitair protocol het niet toe dat je hier vandaag bij kunt zijn maar ik vertel je mijn verhaal een ander keertje. Hans, jouw liefde, rust en onvoorwaardelijke steun zijn essentieel voor de goede balans in mijn leven.

Ik heb gezegd.

\section{Referenties}

Blakemore SJ, Robbins TW. Decision making in the adolescent brain. Nature Neuroscience 2012; 15 (9):1184-1191.

Cohen G, Klaassen RMC, Rietdijk J, Dragt S, van der Gaag M. Twee patienten met verhoogd risico op een eerste psychose. Tijdschrift voor psychiatrie 2012;54(4):471-474

Crone E, Dahl R. Understanding adolescence as a period of social-affective engagement and goal flexibility. Nature Neuro Reviews 2012;13:636-650

Costello EJ, Egger H, Angold A. A 10-year research update review: the epidemiology of child and adolescent psychiatric disorders:I. Methods and public health burden. Journal of American Academy of Child and Adolescent Psychiatry 2005;44:972-986.

Fusar-Poli P, Byrne M, Badger S, Valmaggia LR, McGuire PK.Outreach and support in South London (OASIS), 2001-2011: Ten years of early diagnosis and treatment for young individuals at high clinical risk for psychosis. Eur Psychiatry. 2012 Nov 5.

Fusar-Poli P, Nelson B, Valmaggia L, Yung AR, McGuire PK. Comorbid Depressive and Anxiety Disorders in 509 Individuals With an At-Risk Mental State: Impact on Psychopathology and Transition to Psychosis. Schizophr Bull. 2012 Nov 22. 
van der Gaag M, Nieman DH, Rietdijk J, Dragt S, Ising HK, Klaassen RM, Koeter M, Cuijpers $\mathrm{P}$, Wunderink $\mathrm{L}$, Linszen $\mathrm{DH}$. Cognitive behavioral therapy for subjects at ultrahigh risk for developing psychosis: a randomized controlled clinical trial. Schizophr Bull. 2012 Nov;38(6):1180-8.

De Girolamo G, Dagani J, Purcell R, Cocchi A, McGorry PD. Age of onset of mental disorders and use of mental health services: needs, opportunities and obstacles. Epidemiology and Psychiatric Sciences 2012;21(1):47-57

van den Heuvel MP, Stam CJ, Kahn RS, Hulshoff Pol HE. Efficiency of functional brain networks and intellectual performance. J Neurosc 2009;29;7619-7624

Insel TR \& Fenton WS. Psychiatric epidemiology; it's not just about counting anymore. Archives of General Psychiatry 2005;62:590-592.

Johnson SB, Blum RW, Giedd JN. Adolescent maturity and the brain: the promise and pitfalls of neuroscience research in adolescent health policy. J Adolesc Health. 2009; 45(3):216-21.

Kessler R, Bergland P, Demler O, Jin R, Walters EE. Lifetime prevalence and age-of-onset distributions of DSM-IV disorders in the National Comorbidity Survey Replication. Arch Gen Psychiatry 2005;62:593-602.

Reef J, van Meurs I, Verhulst FC, van der Ende J.Children's problems predict adults' DSM-IV disorders across 24 years. J Am Acad Child Adolesc Psychiatry. 2010 Nov;49(11):1117-24.

Sawyer SM, Afifi RA, Bearinger LH, Blakemore SJ, Dick B, Ezeh AC, Patton GC.

Adolescence: a foundation for future health. Lancet 2012;379: 1630-1640

Schrander-Stumpel CT, Sinnema M, van den Hout L, Maaskant MA, van Schrojenstein Lantman-de Valk HM, Wagemans A, Schrander JJ, Curfs LM. Healthcare transition in persons with intellectual disabilities: general issues, the Maastricht model, and Prader-Willi syndrome. Am J Med Genet C Semin Med Genet. 2007 Aug 15;145 C(3):241-7. Review

Shatkin JP, Belfer ML. The global absence of child and adolescent mental health policy. Child and Adolescent Mental Health 2004;9:104-108.

Shakespeare W. A Winter's Tale, 1623. 
Singh SP, Paul M, Ford T, Kramer T, Weaver T, McLaren S, Hovish K, Islam Z, Belling R, White S. Process, outcome and experience of transition from child to adult mental health care: multiperspective study. Brit J Psychiatry 2010;197: 305-312

da Silva Alves F, Schmitz N, Figee M, Abeling N, Hasler G, van der Meer J, Nederveen A, de Haan L, Linszen D, van Amelsvoort T. Dopaminergic modulation of the human reward system: a placebo-controlled dopamine depletion fMRI study. J Psychopharmacol. 2011; 25(4):538-49.

Sisk CL \& Zehr JL. Pubertal hormones organize the adolescent brain and behaviour. Front. Neuroendocrinol. 2005;26:163-174.

Trimbos Instituut. Bridging-the-Gap: onderzoek kwaliteit van leven bij jongeren met een psychose, 2012.

Velthorst E, Nieman DH, Klaassen RM, Becker HE, Dingemans PM, Linszen DH, De Haan L. Three-year course of clinical symptomatology in young people at ultra high risk for transition to psychosis. Acta Psychiatr Scand. 2011 Jan;123(1):36-42

WHO. Global health risks: mortality and burden of disease attributable to selected major risks. Geneva: World Health Organization, 2009.

Yap MB, Reavley N, Jorm AF. Where would young people seek help for mental disorders and what stops them? Findings from an Australian national survey. J Affect Disord. 2012 Dec 7 